\title{
Desulfocella halophila gen. nov., sp. nov., a halophilic, fatty-acid-oxidizing, sulfate- reducing bacterium isolated from sediments of the Great Salt Lake
}

\author{
Kristian K. Brandt, ${ }^{1,2}$ Bharat K. C. Patel $^{2}$ and Kjeld Ingvorsen ${ }^{1}$ \\ Author for correspondence: Kjeld Ingvorsen. Tel: +45894232 45. Fax: +4586127191. \\ e-mail: Kjeld.Ingvorsen@biology.aau.dk
}

\footnotetext{
1 Department of Microbial Ecology, Institute of Biological Sciences, University of Aarhus, Ny Munkegade, Building 540 , DK-8000 Aarhus C, Denmark

2 Faculty of Science and Technology, Griffith University, Nathan, Brisbane 4111, Australia
}

\begin{abstract}
A new halophilic sulfate-reducing bacterium, strain GSL-But2 ${ }^{\top}$, was isolated from surface sediment of the Southern arm of the Great Salt Lake, UT, USA. The organism grew with a number of straight-chain fatty acids $\left(C_{4}-C_{16}\right), 2$ methylbutyrate, L-alanine and pyruvate as electron donors. Butyrate was oxidized incompletely to acetate. Sulfate, but not sulfite or thiosulfate, served

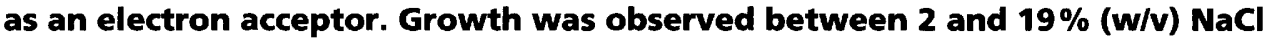
with an optimum at 4-5\% (w/v) $\mathbf{~ N a C l}$. The optimal temperature and pH for growth were around $34{ }^{\circ} \mathrm{C}$ and $\mathrm{pH}$ 6.5-7.3, respectively. The generation time under optimal conditions in defined medium was around $28 \mathrm{~h}$, compared to $20 \mathrm{~h}$ in complex medium containing yeast extract. The $\mathrm{G}+\mathrm{C}$ content was $35.0 \mathrm{~mol} \%$. 165 rRNA gene sequence analysis revealed that strain GSL-But2 ${ }^{\top}$ belongs to the family Desulfobacteriaceae within the delta-subclass of the Proteobacteria and suggested that strain GSL-But2 ${ }^{\top}$ represents a member of a new genus. The name Desulfocella halophila gen. nov., sp. nov. is proposed for this organism. The type strain of D. halophila is strain GSL-But2 ${ }^{\top}$ (= DSM $11763^{\top}$ = ATCC 700426').
\end{abstract}

Keywords: Desulfocella halophila, halophilic sulfate-reducing bacteria, long-chain fatty acids, taxonomy

\section{INTRODUCTION}

The occurrence of dissimilatory sulfate-reduction in hypersaline environments has been known for several decades (ZoBell, 1958). More recent studies indicate that bacterial sulfate reduction is the most important anaerobic mineralization process in hypersaline microbial mats and sediments (Canfield \& Des Marais, 1993; Caumette et al., 1994; Jørgensen \& Cohen, 1977; Skyring, 1987). However, not until recently have the first dissimilatory sulfate-reducing bacteria (SRB) from a wide range of hypersaline habitats been isolated and phylogenetically described (Brandt \& Ingvorsen, 1997; Caumette et al., 1991; Krekeler et al., 1997; Nga et al., 1996; Ollivier et al., 1991; Tardy-Jacquenod et al., 1996, 1998; Zhilina et al., 1997). With the exception

Abbreviation: SRB, sulfate-reducing bacteria.

The GenBank accession number for the $16 \mathrm{~S}$ rDNA sequence of strain GSLBut2 ${ }^{\top}$ is AF022936. of the acetate-oxidizing Desulfobacter halotolerans (Brandt \& Ingvorsen, 1997), all these strains share the ability to oxidize lactate, molecular hydrogen and other substrates typically metabolized by members of the genus Desulfovibrio. Other types of SRB capable of growing on higher fatty acids and benzoate have been reported from hypersaline oilfields (Cord-Ruwisch et al., 1987). However, these species were not sufficiently described to allow for a taxonomic affiliation with existing SRB. Hence nothing is known about the physiology and phylogeny of long-chain fatty acidoxidizing SRB in hypersaline environments.

As a part of our investigations on the ecology and diversity of SRB in hypersaline environments, here we provide the characterization of a new butyrate- and higher fatty-acid-oxidizing, sulfate-reducing bacterium isolated from the Great Salt Lake, UT, USA. Phylogenetic analysis as well as other characteristics suggest that this strain, designated GSL-But2 ${ }^{\mathrm{T}}$, is a representative of a new genus and a new species for 

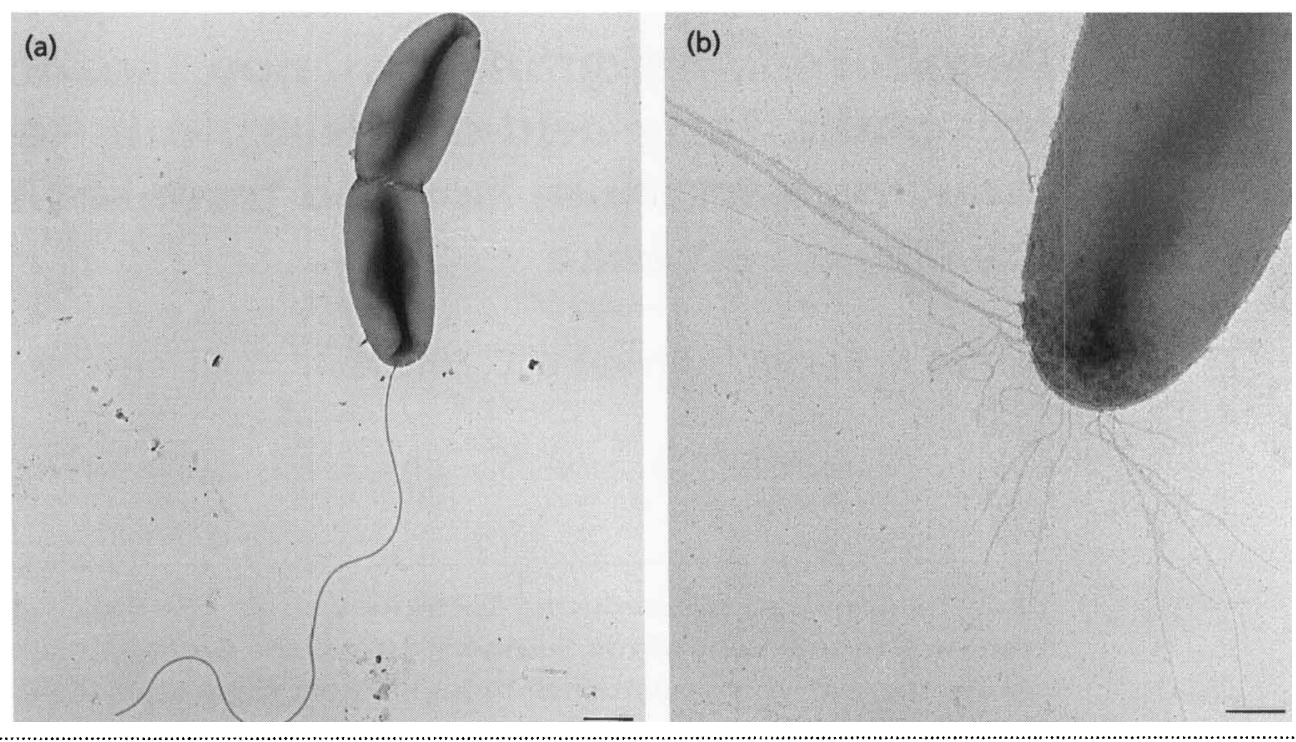

Fig. 1. Transmission electron micrographs of Desulfocella halophila strain GSL-But2 ${ }^{\top}$ after negative staining. (a) Dividing cell showing the polar flagellum; bar, $0.5 \mu \mathrm{m}$. (b) The polar region showing polar appendages; bar, $0.2 \mu \mathrm{m}$.

which we propose the name Desulfocella halophila gen. nov., sp. nov.

\section{METHODS}

Source of strains. Strain GSL-But $2^{\mathrm{T}}$ and physiologically similar strains were isolated from surface sediment collected from the Southern arm of the Great Salt Lake at 8-10 m depth (station AS2; Utah Geological Survey station code).

Isolation and media. Strains of SRB were initially enriched in Medium E (Brandt \& Ingvorsen, 1997) containing $100 \mathrm{~g}$ $\mathrm{NaCl}^{-1}$ and a mixture of acetate $(10 \mathrm{mM})$, propionate $(10 \mathrm{mM})$ and butyrate $(5 \mathrm{mM})$. A modified defined medium, Medium I (Brandt \& Ingvorsen, 1997), containing $100 \mathrm{~g}$ $\mathrm{NaCl} 1^{-1}$ and butyrate $(15 \mathrm{mM})$ as the sole electron donor was employed for all subsequent enrichments/isolations. Pure cultures were obtained by repeated use of deep agar dilution series (Widdel \& Bak, 1992). If not stated otherwise, growth experiments were performed in Medium I $(50 \mathrm{~g} \mathrm{NaCl}$ $1^{-1}$ ) with butyrate and sulfate as growth substrates ( 27 or $30^{\circ} \mathrm{C}, \mathrm{pH} 6 \cdot 9-7 \cdot 3$ ).

Morphology. Gram staining was performed as described by Dussault (1955). Exponentially growing cells were negatively stained with $1 \%(\mathrm{w} / \mathrm{v})$ uranyl acetate and subsequently viewed with a JEOL 1200 EX transmission electron microscope.

Analytical techniques. Hydrogen sulfide was analysed spectrophotometrically (Cord-Ruwisch, 1985). Fatty acids were quantified by HPLC analysis using an Aminex HPX$87 \mathrm{H}$ ion exclusion column (Bio-Rad) and UV detection as previously described (Brandt \& Ingvorsen, 1997).

Lipid analysis and fatty acid nomenclature. Strain GSLBut $2^{\mathrm{T}}$ was cultivated in the standard medium of Vainshtein et al. (1992) supplemented with $50 \mathrm{~g} \mathrm{NaCl}^{-1}$ and $20 \mathrm{mM}$ butyrate. Cells were harvested by centrifugation $(16000 \mathrm{~g})$, freeze-dried and analysed according to Vainshtein et al.
(1992). The fatty acid analysis was performed by Professor Dr Reiner M. Kroppenstedt at DSMZ (Braunschweig, Germany) and the fatty acid nomenclature of Vainshtein $e t$ al. (1992) was used.

$\mathbf{G}+\mathbf{C}$ content of genomic DNA and characterization of pigments. The $\mathrm{G}+\mathrm{C}$ content of genomic DNA was determined at the Identification Service of the DSMZ (Braunschweig, Germany) by Dr Jutta Burghardt. Genomic DNA from strain GSL-But $2^{\mathrm{T}}$ was isolated and purified according to Visuvanathan et al. (1989) and the G+C content was determined by HPLC analysis (Mesbah et al., 1989; Tamaoka \& Komagata, 1984). The presence of desulfoviridin was investigated in cell extracts as described previously by Widdel \& Pfennig (1981).

16S rRNA gene sequencing and phylogenetic analysis. Genomic DNA from strain GSL-But $2^{\mathrm{T}}$ was isolated by the method of Porteuous et al. (1994). A primer pair, designated Fd1 (5' CAGAGTTTGATCCTGGCTCAG $\left.3^{\prime}\right)$ and Rd1 (5' AAGGAGGTGATCCAGCC $3^{\prime}$ ) was used for PCR amplification of the 16S rRNA gene. The PCR product was purified by using QIAEX (QIAGEN) as described by the manufacturer. The purified PCR product was subsequently sequenced at Griffith University with an Applied Biosystems model 373A automated DNA sequencer by using a Prism dideoxy terminator cycle sequencing kit and by following the recommended protocol of the manufacturer (Applied Biosystems). The primers used for sequencing were $\mathrm{Fdl}, \mathrm{Fl}$ (5' CTCCTACGGGAGGCAGCAG 3'), F3 (5' AAACTCAAAGGAATTGACGG 3'), F4 (5' TGTACACACCGCCCGT 3'), R1 (5' CTGCTGCCTCCCGTAG 3'), R2 (5' GTATTACCGCGGCTGCTG $\left.3^{\prime}\right)$, R4 (5' CCGTCAATTCCTTTGAGTTT 3'), R5 (5' GGGGTTGCGCTCGTTG $\left.3^{\prime}\right)$, R6 (5' TACGGTTACCTTGTTACGAC $\left.3^{\prime}\right)$ and Rd1.

The 16S rRNA gene sequence was manually aligned against representative sequences from the delta-subclass of the Proteobacteria using the alignment editor ae2 (Maidak et al., 1997). Pairwise evolutionary distances were calculated ac- 
Table 1. Morphological and physiological characteristics of Desulfocella halophila strain GSL-But2 ${ }^{\top}$ as compared to the closest relatives among the dissimilatory sulfate-reducing bacteria

ND, Not done. Final concentrations (mM) of the electron donors/acceptors tested are given in parentheses. The sulfate concentration of the medium was $40.6 \mathrm{mM}$. Saturated unbranched fatty acids were added at concentrations recommended by Widdel \& Bak (1992). The following electron donors were not utilized by strain GSL-But2 ${ }^{\mathrm{T}}:$ L-arginine (7.5), L-asparagine (5), betaine (10), 1-butanol (10), capric acid (10), citrate (10), L-cysteine (10), fructose (10), glucose (10), glutamate (10), glycerol (10), glycine (10), L-isoleucine (5), L-leucine (5), L-methionine (5), L-serine (10), thioglycolate (2.5), L-threonine (7.5), L-tryptophan (2) or xylose (10). Fe(III)-citrate (20), nitrate (10), elemental sulfur or fumarate (10) were not used as electron acceptors by strain GSL-But2 ${ }^{\mathrm{T}}$. Symbols used: + , good growth; + (auto), autotrophic growth; $(+)$, slow growth;,- no growth.

\begin{tabular}{|c|c|c|c|c|c|}
\hline & $\begin{array}{l}\text { Desulfocella } \\
\text { halophila }\end{array}$ & $\begin{array}{l}\text { 'Desulfobotulus } \\
\text { sapovorans'* }\end{array}$ & $\begin{array}{c}\text { Desulfococcus } \\
\text { multivorans* }\end{array}$ & $\begin{array}{l}\text { Desulfosarcina } \\
\text { variabilis* }\end{array}$ & $\begin{array}{c}\text { Desulfobacterium } \\
\text { autotrophicum } \dagger\end{array}$ \\
\hline Cell shape & Vibrio & Vibrio & Spherical & $\begin{array}{l}\text { Oval (form } \\
\text { aggregates) }\end{array}$ & Oval rod \\
\hline Width $(\mu \mathrm{m})$ & $0.5-0.7$ & 1.5 & $1 \cdot 5-2 \cdot 2$ & $1-1.5$ & $1-1 \cdot 5$ \\
\hline Length $(\mu \mathrm{m})$ & $2-4$ & $3-5 \cdot 5$ & - & $1 \cdot 5-2 \cdot 5$ & $1 \cdot 5-2 \cdot 5$ \\
\hline Vitamin requirement & None & None & $\begin{array}{l}\text { 4-Aminobenzoate, } \\
\text { biotin, thiamin }\end{array}$ & None & $\begin{array}{r}\text { 4-Aminobenzoate, } \\
\text { biotin, nicotinate }\end{array}$ \\
\hline Motility: & $\begin{array}{l}+(\text { polar } \\
\text { flagellum })\end{array}$ & $\begin{array}{c}+(\text { polar } \\
\text { flagellum })\end{array}$ & - & $\begin{array}{c}+/-(\text { polar } \\
\text { flagellum })\end{array}$ & $+($ polar flagellum $)$ \\
\hline \multicolumn{6}{|l|}{ Electron donors: } \\
\hline $\mathrm{H}_{2}$ & - & - & - & + (auto) & + (auto) \\
\hline Formate (10) & - & - & + (auto) & + (auto) & +(auto) \\
\hline Acetate (10) & - & - & $(+)$ & $(+)$ & $(+)$ \\
\hline Propionate (10) & - & - & + & + & $(+)$ \\
\hline Fatty acids (C-atoms) & $4-6,8,12,16$ & $4-16$ & $4-16$ & $4-14$ & $4-16$ \\
\hline Isobutyrate (10) & - & - & + & - & + \\
\hline 2-Methylbutyrate (10) & + & + & + & $(+)$ & + \\
\hline 3-Methylbutyrate (10) & - & - & + & $(+)$ & - \\
\hline lactate $(10)$ & - & + & + & + & + \\
\hline Ethanol (20) & - & - & + & + & + \\
\hline Pyruvate (10) & + & + & + & + & + \\
\hline Benzoate (2) & - & - & + & + & - \\
\hline Succinate (10) & - & - & - & + & + \\
\hline Fumarate (10) & - & - & - & + & + \\
\hline Malate (10) & - & - & - & - & + \\
\hline L-Alanine (10) & + & ND & ND & ND & ND \\
\hline $\begin{array}{l}\text { Oxidation of energy } \\
\text { substrate }\end{array}$ & Incomplete & Incomplete & Complete & Complete & Complete \\
\hline \multicolumn{6}{|l|}{ Electron acceptors: } \\
\hline Sulfate & + & + & + & + & + \\
\hline Sulfite $(2-5)$ & - & + & + & + & - \\
\hline Thiosulfate $(5-10)$ & - & - & + & + & + \\
\hline $\begin{array}{l}\text { Shortest doubling time (h) } \\
\text { on butyrate }+ \text { sulfate }\end{array}$ & $28(20) \ddagger$ & 15 & - & - & - \\
\hline $\begin{array}{l}\text { Optimum temperature } \\
\left({ }^{\circ} \mathrm{C}\right)\end{array}$ & 34 & 34 & 35 & 33 & $25-28$ \\
\hline $\begin{array}{l}\text { Optimum salinity (\% } \\
\mathrm{NaCl}, \mathrm{w} / \mathrm{v})\end{array}$ & $4-5$ & $0 \cdot 1-0 \cdot 7$ & $0 \cdot 7-2 \cdot 0$ & $1 \cdot 3$ & 2 \\
\hline Optimum pH & $7 \cdot 0$ & $7 \cdot 7$ & $7 \cdot 3$ & $7 \cdot 4$ & 6.7 \\
\hline Desulfoviridin & - & - & + & - & - \\
\hline $\begin{array}{l}\mathrm{G}+\mathrm{C} \text { content of DNA } \\
(\mathrm{mol} \%)\end{array}$ & 35 & 53 & 57 & 51 & 48 \\
\hline
\end{tabular}

* Widdel (1980).

$\dagger$ Brysch et al. (1987).

$\ddagger$ Value in parentheses refers to growth in complex medium containing $1 \mathrm{~g}$ yeast extract $\mathrm{l}^{-1}$. 
cording to the method of Jukes \& Cantor (1969) by using 992 unambiguous nucleotides. Dendrograms were constructed by the neighbour-joining method (Saitou \& Nei, 1987) using part of the PHYLIP software package (Felsenstein, 1993). The topology of the tree was confirmed by bootstrap analysis. Sequences for phylogenetic analysis were retrieved from the Ribosomal Database Project (Maidak et al., 1997) or from GenBank.

Culture collections. Strain GSL-But $2^{\mathrm{T}}$ has been deposited at the DSMZ (Braunschweig, Germany) as DSM 11763 and at the ATCC (Manassas, VA, USA) as ATCC 700426.

\section{RESULTS}

\section{Enrichment and isolation}

After 4 weeks incubation in liquid Medium $\mathrm{E}$ enrichment, cultures consisting of different cell morphologies showed intensive sulfide production. Subsequent transfers $(5 \% \mathrm{v} / \mathrm{v})$ in Medium I with butyrate as the only electron donor resulted in cultures with a predominance of $0.5-0.7 \mu \mathrm{m}$ thick and $2-4 \mu \mathrm{m}$ long vibrios. Thicker Desulfobacter-like rods with rounded ends were also present. Several pure cultures of the predominant vibrios were obtained after repeated serial dilutions in agar-containing medium. One isolate designated GSL-But $2^{\mathrm{T}}$, showing only a weak tendency to clump during growth, was chosen for further studies.

\section{Morphology}

Cells of strain GSL-But2 ${ }^{\mathrm{T}}$ consisted of $0 \cdot 5-0 \cdot 7 \mu \mathrm{m}$ thick and $2-4 \mu \mathrm{m}$ long vibrios (Fig. 1a). Cells were motile by means of a single polar flagellum and possessed polar filamentous appendages (Fig. 1b). Spores were never observed. Strain GSL-But2 ${ }^{\mathrm{T}}$ stained Gram-negative.

\section{Metabolism and growth characteristics}

The growth characteristics of strain GSL-But $2^{\mathrm{T}}$ and its closest relatives are listed in Table 1. Strain GSL-But2 ${ }^{\mathbf{T}}$ grew well on butyrate and most higher fatty acids up to palmitate in the presence of sulfate. The branched fatty acid 2-methylbutyrate also yielded good growth. Lalanine and pyruvate were also good substrates albeit with a low production of sulfide (around $1 \mathrm{mM}$ ). The reason for the low production of sulfide during growth on alanine and pyruvate is not known. There was no growth with molecular hydrogen or formate as electron donors in Medium I supplemented with $2 \mathrm{mM}$ acetate as a carbon source. Of the electron acceptors tested (Table 1), sulfate was the only one that supported growth with butyrate as the electron donor. Butyrate, L-alanine or pyruvate did not support growth of strain GSL-But $2^{\mathrm{T}}$ in sulfate-free medium. In the presence of sulfate, butyrate was incompletely oxidized to acetate. From $1 \mathrm{~mol}$ butyrate, $1.94 \mathrm{~mol}$ acetate was excreted into the medium along with $0.47 \mathrm{~mol}$ hydrogen sulfide. The molar ratios of bu-

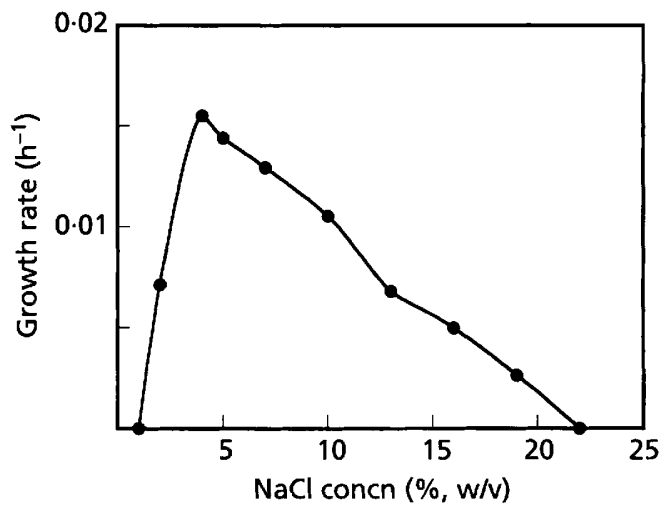

Fig. 2. Effect of $\mathrm{NaCl}$ concentration on growth rate of Desulfocella halophila strain GSL-But $2^{\top}$ grown on butyrate and sulfate at $27^{\circ} \mathrm{C}$.

tyrate dissimilated and acetate and sulfide excreted thus agreed well with the following equation:

$2 \mathrm{CH}_{3}\left(\mathrm{CH}_{2}\right)_{2} \mathrm{COO}^{-}+\mathrm{SO}_{4}^{2-} \rightarrow 4 \mathrm{CH}_{3} \mathrm{COO}^{-}+\mathrm{HS}^{-}+\mathrm{H}^{+}$

Strain GSL-But2 $2^{\mathrm{T}}$ grew between 14 and $37^{\circ} \mathrm{C}$ with an optimum at around $34^{\circ} \mathrm{C}$. Growth occurred between 2 and $19 \%(\mathrm{w} / \mathrm{v}) \mathrm{NaCl}$ with an optimum at $4-5 \%(\mathrm{w} / \mathrm{v})$ $\mathrm{NaCl}$ (Fig. 2). Strain GSL-But2 ${ }^{\mathrm{T}}$ grew between $\mathrm{pH} 5 \cdot 8$ and 7.6 but not at $\mathrm{pH} 5.5$ or 8.2 , with maximal growth rates at $\mathrm{pH} 6 \cdot 5-7 \cdot 3$. The optimal magnesium concentration for growth was $2-100 \mathrm{mM}$ although at $620 \mathrm{mM} \mathrm{Mg} \mathrm{Mg}^{2+}$, growth still occurred at about onethird of the maximal growth rate. Yeast extract stimulated growth considerably, reducing the doubling time from 28 to $20 \mathrm{~h}$ when grown at $30^{\circ} \mathrm{C}$. This growth stimulation was dose-independent from 0.25 to $2 \mathrm{~g}$ yeast extract $1^{-1}$.

\section{Phylogenetic analysis}

A total of 1547 bases from position 8 to position 1547 (Escherichia coli numbering) of the 16S rRNA gene of strain GSL-But $2^{\mathrm{T}}$ were sequenced. The phylogenetic analysis clearly showed that strain GSL-But $2^{\mathrm{T}}$ belongs to the delta-subclass of the Proteobacteria (Fig. 3; Table 2). Strain GSL-But $2^{\mathrm{T}}$ was only distantly related to known species of SRB and was found to belong to a new branch within the proposed family Desulfobacteriaceae. Bootstrap analysis confirmed the topology of the neighbour-joining-based dendrogram indicating that strain GSL-But $2^{\mathrm{T}}$ might form a monophyletic group with 'Desulfobotulus sapovorans'. However, the relationship between the two strains was not robust ( $57 \%$ bootstrap).

\section{$G+C$ content of genomic DNA and characterization of pigments}

The $\mathrm{G}+\mathrm{C}$ content of the genome of strain GSL-But $2^{\mathrm{T}}$ was $35.0 \mathrm{~mol} \%$. The cells did not contain desulfoviridin. 


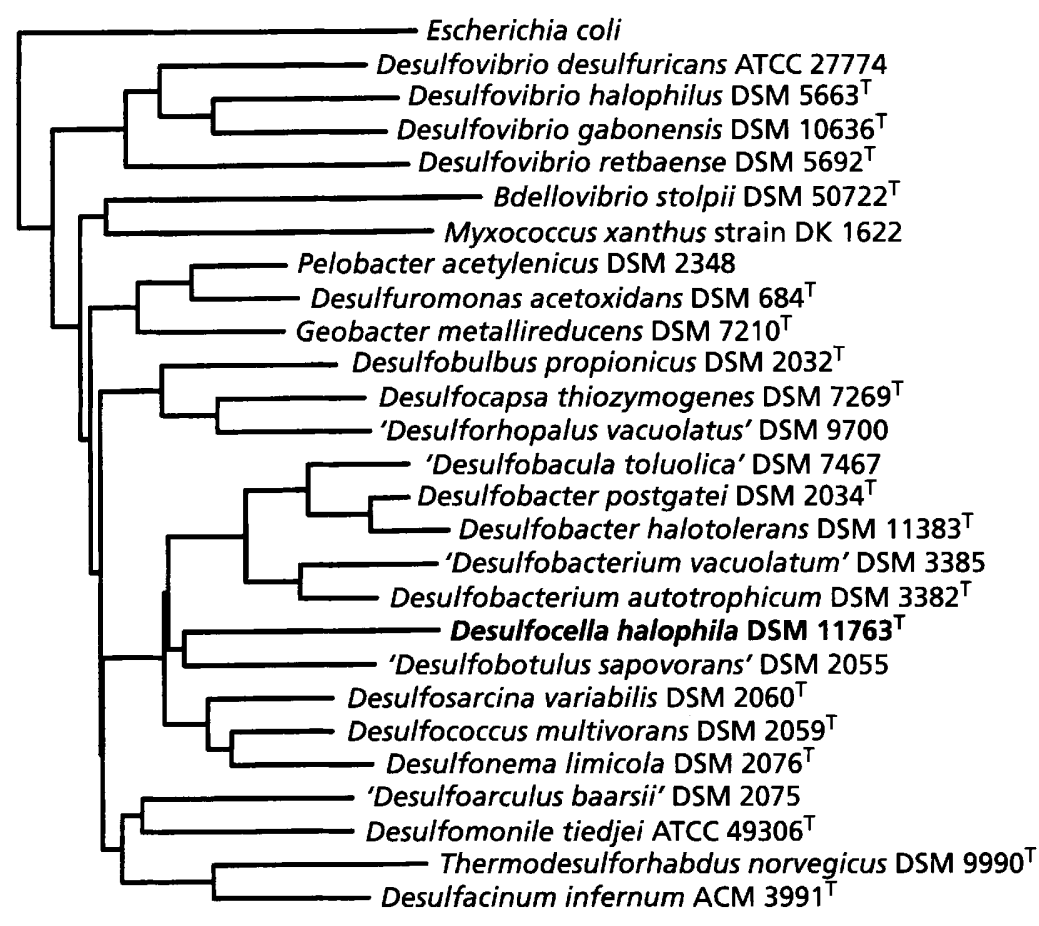

0.10
Fig. 3. Dendrogram showing the phylogenetic position of Desulfocella halophila strain GSL-But2 ${ }^{\top}$ compared to some of the closest relatives among the delta-subclass of the Proteobacteria. Escherichia coli was used as the outgroup.

Table 2. 165 rDNA similarity values between Desulfocella halophila strain GSL-But2 ${ }^{\top}$ and related taxa within the deltasubclass of the Proteobacteria

\begin{tabular}{|c|c|c|c|c|c|c|c|c|c|c|c|c|c|c|c|c|}
\hline Species & 1 & 2 & 3 & 4 & 5 & 6 & 7 & 8 & 9 & 10 & 11 & 12 & 13 & 14 & 15 & 16 \\
\hline 1 Desulfocella halophila & - & & & & & & & & & & & & & & & \\
\hline 2 'Desulfobotulus sapovorans' & 87.5 & - & & & & & & & & & & & & & & \\
\hline 3 Desulfosarcina variabilis & $87 \cdot 2$ & $88 \cdot 9$ & - & & & & & & & & & & & & & \\
\hline 4 Desulfococcus multivorans & 87.5 & $90 \cdot 1$ & 93.4 & - & & & & & & & & & & & & \\
\hline 5 Desulfonema limicola & 85.5 & $89 \cdot 5$ & $91 \cdot 5$ & $93 \cdot 2$ & - & & & & & & & & & & & \\
\hline 6 'Desulfobacula toluolica' & $85 \cdot 0$ & $86 \cdot 8$ & 88.0 & $86 \cdot 7$ & $85 \cdot 7$ & - & & & & & & & & & & \\
\hline 7 'Desulfobacterium vacuolatum' & $86 \cdot 3$ & $87 \cdot 1$ & 88.9 & $87 \cdot 4$ & $86 \cdot 4$ & $90 \cdot 4$ & - & & & & & & & & & \\
\hline 8 Desulfobacterium autotrophicum & $86 \cdot 4$ & $89 \cdot 0$ & $90 \cdot 4$ & $89 \cdot 0$ & $88 \cdot 7$ & $92 \cdot 1$ & $84 \cdot 0$ & - & & & & & & & & \\
\hline 9 Desulfobacter postgatei & $85 \cdot 6$ & $86 \cdot 3$ & $88 \cdot 5$ & $87 \cdot 1$ & $85 \cdot 5$ & $93 \cdot 9$ & $89 \cdot 6$ & $90 \cdot 7$ & - & & & & & & & \\
\hline 10 Desulfobacter halotolerans & $84 \cdot 2$ & $85 \cdot 5$ & $86 \cdot 7$ & $86 \cdot 3$ & $85 \cdot 6$ & $93 \cdot 7$ & $89 \cdot 3$ & $90 \cdot 4$ & $96 \cdot 7$ & & & & & & & \\
\hline 11 Desulfobulbus propionicus & $83 \cdot 7$ & $84 \cdot 5$ & $87 \cdot 4$ & $85 \cdot 0$ & $85 \cdot 0$ & $86 \cdot 1$ & $83 \cdot 6$ & $85 \cdot 3$ & $86 \cdot 1$ & $84 \cdot 5$ & - & & & & & \\
\hline 12 'Desulforhopalus vacuolatus" & $84 \cdot 4$ & $85 \cdot 0$ & $85 \cdot 4$ & $85 \cdot 3$ & $84 \cdot 1$ & $85 \cdot 0$ & $83 \cdot 1$ & $84 \cdot 7$ & $84 \cdot 2$ & $82 \cdot 7$ & $89 \cdot 3$ & - & & & & \\
\hline 13 Desulfocapsa thiozymogenes & $84 \cdot 5$ & $84 \cdot 2$ & $86 \cdot 1$ & $86 \cdot 2$ & $86 \cdot 3$ & $83 \cdot 7$ & $81 \cdot 9$ & $83 \cdot 7$ & $83 \cdot 6$ & $82 \cdot 7$ & $89 \cdot 2$ & $91 \cdot 6$ & - & & & \\
\hline 14 'Desulfoarculus baarsii' & $83 \cdot 3$ & $86 \cdot 3$ & 86.8 & $88 \cdot 1$ & $86 \cdot 4$ & $84 \cdot 1$ & $82 \cdot 9$ & 83.6 & 83.9 & $82 \cdot 7$ & $85 \cdot 4$ & $84 \cdot 4$ & $83 \cdot 1$ & - & & \\
\hline 15 Pelobacter acetylenicus & $84 \cdot 5$ & $86 \cdot 1$ & 87.1 & $86 \cdot 6$ & 85.5 & $85 \cdot 2$ & $83 \cdot 9$ & $86 \cdot 3$ & $86 \cdot 0$ & $83 \cdot 7$ & $86 \cdot 7$ & $86 \cdot 5$ & $86 \cdot 6$ & $86 \cdot 8$ & - & \\
\hline 16 Desulfovibrio halophilus & $80 \cdot 5$ & $80 \cdot 1$ & 82.5 & $82 \cdot 8$ & $80 \cdot 7$ & $79 \cdot 8$ & $79 \cdot 3$ & $79 \cdot 5$ & $79 \cdot 6$ & 77.8 & $82 \cdot 0$ & $82 \cdot 4$ & $81 \cdot 5$ & $85 \cdot 1$ & $83 \cdot 1$ & - \\
\hline
\end{tabular}

\section{Lipid analysis and fatty acid nomenclature}

Strain GSL-But $2^{\mathrm{T}}$ contained mainly unbranched saturated and unsaturated fatty acids (Table 3 ). In addition, a small amount of $\beta$-hydroxy-myristic acid $(14: 03-\mathrm{OH})$ was present. The fatty acid composition of strain GSL-But $2^{\mathrm{T}}$ comprised 14:0 (2.3\%), 14:0 3$\mathrm{OH}+15: 0$ dma $(6.5 \%), 16: 1 \quad c 7 \quad(2 \cdot 1 \%), 16: 1 \quad c 9$ $(5.1 \%), 16: 1 \quad c 11(1.3 \%), 16: 0(36.5 \%), 18: 1 c 9$ $(25 \cdot 8 \%), 18: 1 c 11(16 \cdot 7 \%), 18: 0(1 \cdot 1 \%)$, and $20: 1 c 11$ $(2 \cdot 6 \%) .14: 03-\mathrm{OH}$ and 15:0 dma fell into the same retention time window and are therefore listed together.

\section{DISCUSSION}

Strain GSL-But $2^{\mathrm{T}}$ is the first very halotolerant sulfate reducer described which is able to use long-chain fatty acids and L-alanine as electron donors. The bottom waters of the Southern arm of the Great Salt Lake are moderately hypersaline with a $\mathrm{NaCl}$ and $\mathrm{Mg}^{2+}$ content of approximately $130 \mathrm{~g} \mathrm{l}^{-1}(2.2 \mathrm{M})$ and $4.5 \mathrm{~g} \mathrm{l}^{-1}$ $(185 \mathrm{mM})$, respectively (W. Gwynn, personal communication). Strain GSL-But2 ${ }^{\mathrm{T}}$ thus seems to be relatively well adapted to its natural habitat, although it prefers lower salinities of $40-50 \mathrm{~g} \mathrm{l}^{-1}$. The growth response of strain GSL-But $2^{\mathrm{T}}$ to $\mathrm{NaCl}$ hence displayed 
Table 3. Cellular fatty acid composition (\%) of Desulfocella halophila strain GSL-But2 ${ }^{\top}$ from this study and previously published data on its closest relatives among the Gram-negative SRB

\begin{tabular}{|c|c|c|c|c|c|c|}
\hline \multirow[t]{2}{*}{ Fatty acid } & \multirow[t]{2}{*}{$\begin{array}{c}\text { Desulfocella } \\
\text { halophila }\end{array}$} & \multicolumn{2}{|c|}{$\begin{array}{l}\text { 'Desulfobotulus } \\
\text { sapovorans' }\end{array}$} & \multirow[t]{2}{*}{$\begin{array}{c}\text { Desulfococcus } \\
\text { multivorans } \dagger\end{array}$} & \multirow[t]{2}{*}{$\begin{array}{c}\text { Desulfosarcina } \\
\text { variabilis } \dagger\end{array}$} & \multirow[t]{2}{*}{$\begin{array}{c}\text { Desulfobacterium } \\
\text { autotrophicum }\end{array}$} \\
\hline & & * & $\dagger$ & & & \\
\hline \multicolumn{7}{|l|}{ Saturated unbranched } \\
\hline $\begin{array}{l}\text { even numbered } \\
\text { odd numbered }\end{array}$ & $\begin{array}{r}39 \cdot 8 \\
0 \cdot 0\end{array}$ & $\begin{array}{r}32 \cdot 3 \\
0 \cdot 0\end{array}$ & $\begin{array}{r}31 \cdot 2 \\
0.0\end{array}$ & $\begin{array}{r}25 \cdot 2 \\
4 \cdot 0\end{array}$ & $\begin{array}{r}29 \cdot 6 \\
4 \cdot 0\end{array}$ & $\begin{array}{r}17 \cdot 5 \\
8 \cdot 2\end{array}$ \\
\hline \multicolumn{7}{|l|}{ Branched } \\
\hline iso & 0.0 & $5 \cdot 1$ & 0.0 & $5 \cdot 5$ & $4 \cdot 3$ & $0 \cdot 0$ \\
\hline anteiso & $0 \cdot 0$ & $28 \cdot 8$ & $0 \cdot 0$ & $35 \cdot 8$ & $39 \cdot 6$ & $0 \cdot 0$ \\
\hline Unsaturated & $53 \cdot 7$ & $30 \cdot 6$ & $61 \cdot 5$ & $21 \cdot 2$ & $18 \cdot 3$ & $54 \cdot 7$ \\
\hline
\end{tabular}

* From Vainshtein et al. (1992). Same culture conditions and analysis protocol as used for our study.

$\dagger$ From Kohring et al. (1994).

the same pattern as observed for other sulfate reducers isolated from hypersaline habitats. These strains, when tested in vitro, all exhibited salinity optima for growth significantly below the in situ salinities of their respective habitats (Brandt \& Ingvorsen, 1997; Krekeler et al., 1997; Ollivier et al., 1994).

Phylogenetic analysis of the 16S rRNA gene showed that strain GSL-But $2^{\mathrm{T}}$ formed a new lineage within the proposed family Desulfobacteriaceae, the closest relatives being members of the genera 'Desulfobotulus', Desulfococcus, Desulfosarcina and Desulfobacterium (Table 2; Fig. 3). We therefore propose that strain GSL-But $2^{\mathrm{T}}$ should be recognized as a member of a new genus, Desulfocella gen. nov. However, we did retrieve one 16S rDNA sequence from an unpublished strain tentatively named 'Desulfobotulus BG14' (GenBank accession no. U85470), which was more closely related to strain GSL-But2 ${ }^{\mathrm{T}}(94.9 \%$ similarity) than the others tested. The creation of a new genus to include strain GSL-But $2^{\mathrm{T}}$ is further supported by the very low $\mathrm{G}+\mathrm{C}$ content $(35 \mathrm{~mol} \%)$ of the genomic DNA from strain GSL-But2 ${ }^{\mathbf{T}}$ as compared to the much higher $\mathrm{G}+\mathrm{C}$ content of its closest described relatives (Table 1).

The fatty acid profile of strain GSL-But $2^{\mathrm{T}}$ supported the results of the phylogenetic analysis (Table 3 ). The absence of branched-chain fatty acids thus clearly separates GSL-But2 ${ }^{\mathrm{T}}$ from members of the genus Desulfovibrio (Vainshtein et al., 1992) and from other related genera (Ollivier et al., 1991; Zhilina et al., 1997). Rather, the low level of branching fatty acids and the high level of unsaturated fatty acids suggests a closer relationship to Desulfospira joergensenii (Finster et al., 1997), several Desulfobacterium species (Kohring et al., 1994; Vainshtein et al., 1992) and 'Desulfobotulus sapovorans' (Kohring et al., 1994). The fatty acid profile of 'Desulfobotulus sapovorans' has been found to be strongly influenced by culture conditions and/or techniques for analysis of cellular fatty acids
(Table 3). Strain GSL-But $2^{\mathrm{T}}$ thus differed significantly from 'Desulfobotulus sapovorans', when the two strains were grown and analysed under similar conditions (Table 3). However, in another study, using somewhat different culture conditions and analysis protocols (Kohring et al., 1994), the fatty acid profile obtained for 'Desulfobotulus sapovorans' was found to be more similar to that of strain GSL-But2 ${ }^{\mathrm{T}}$ (Table 3).

Physiologically and morphologically, strain GSLBut $2^{\mathrm{T}}$ differs markedly from most of its closest relatives (Table 1; Widdel \& Bak, 1992). The energy metabolism of strain GSL-But $2^{\mathrm{T}}$, however, resembles that of 'Desulfobotulus sapovorans', in that both species oxidize butyrate and higher fatty acids incompletely with acetate as the end product. Strain GSL-But2 ${ }^{\mathrm{T}}$ can be distinguished from 'Desulfobotulus sapovorans' by being unable to use lactate and sulfite as the electron donor and electron acceptor, respectively. More importantly, strain GSL-But ${ }^{\mathrm{T}}$ differs significantly from the freshwater isolate 'Desulfobotulus sapovorans' with respect to halotolerance and halophily (Table 1).

We here propose that strain GSL-But $2^{\mathrm{T}}$ should be placed in a new genus, Desulfocella, as a new species, Desulfocella halophila.

\section{Description of Desulfocella gen. nov.}

Desulfocella (De.sul.fo.cel'la. L. pref. de from; L. n. sulfur sulfur; L. fem. n. cella small room, cell; M.L. fem. n. Desulfocella sulfate-reducing cell).

Gram-negative, non-spore forming vibrios, motile by a single polar flagellum. Obligatory anaerobic chemoorganotroph; grows with sulfate as electron acceptor and produces hydrogen sulfide. A wide range of fatty acids $\left(\mathrm{C}_{4}-\mathrm{C}_{16}\right)$ serve as electron donors and are incompletely oxidized. Does not grow by fermentation. Mesophilic and neutrophilic with a requirement for $\mathrm{NaCl}$. Vitamins are not required. Yeast extract 
stimulates growth. The $\mathrm{G}+\mathrm{C}$ content of the DNA is around $35 \mathrm{~mol} \%$. Desulfoviridin not present. Phylogenetically a member of the family Desulfobacteriaceae within the delta-subclass of the Proteobacteria. The type species is Desulfocella halophila.

\section{Description of Desulfocella halophila sp. nov.}

Desulfocella halophila (ha.lo' phi.la. Gr. n. hals salt; Gr. adj. philos friendly to; M.L. fem. adj. halophila salt-loving).

Vibrio-shaped cells, $0.5-0.7 \times 2-4 \mu \mathrm{m}$. Motile by means of one polar flagellum. Reduces sulfate, but not thiosulfate, sulfite, elemental sulfur, ferric iron, nitrate or fumarate. Pyruvate, L-alanine, 2-methylbutyrate and many straight-chain saturated fatty acids with 4-16 carbon atoms serve as electron donors. Does not grow by fermentation of pyruvate, L-alanine or butyrate when sulfate is absent. Vitamins are not required, but yeast extract stimulates growth. Temperature range associated with growth, $14-37^{\circ} \mathrm{C}$; optimum around $34{ }^{\circ} \mathrm{C}$. Optimum salinity, 4-5\% (w/v) $\mathrm{NaCl}$; halotolerance, 2-19\% (w/v) NaCl. Grows optimally in the presence of $2-100 \mathrm{mM} \mathrm{Mg}{ }^{2+}$ and tolerates up to $620 \mathrm{mM} \mathrm{Mg}{ }^{2+}$. The $\mathrm{pH}$ range for growth is $5 \cdot 8-7 \cdot 6$ with optimum at $\mathrm{pH} 6 \cdot 5-7 \cdot 3$. The $\mathrm{G}+\mathrm{C}$ content of the DNA is $35.0 \mathrm{~mol} \%$. The type strain, GSL-But2 ${ }^{\mathrm{T}}$, was isolated from hypersaline, thalassohaline sediment of the Great Salt Lake (UT, USA) and has been deposited at the DSMZ (Braunschweig, Germany) as DSM $11763^{\mathrm{T}}$ and at the ATCC (Manassas, VA, USA) as ATCC $700426^{\mathrm{T}}$.

\section{ACKNOWLEDGEMENTS}

We are grateful to Dr Deborah Stenzel from Queensland University of Technology (Brisbane, Australia) for technical assistance (transmission electron microscopy) and for preparing TEM micrographs for publication. We thank Dr Wallace Gwynn from the Utah Geological Survey (Salt Lake City, UT, USA) for providing geochemical data about the Great Salt Lake.

\section{REFERENCES}

Brandt, K. K. \& Ingvorsen, K. (1997). Desulfobacter halotolerans sp. nov., a halotolerant acetate-oxidizing sulfate-reducing bacterium isolated from sediments of Great Salt Lake, Utah. Syst Appl Microbiol 20, 366-373.

Brysch, K., Schneider, C., Fuchs, G. \& Widdel, F. (1987). Lithoautotrophic growth of sulfate-reducing bacteria, and description of Desulfobacterium autotrophicum gen. nov., sp. nov. Arch Microbiol 148, 264-274.

Canfield, D. E. \& Des Marais, D. J. (1993). Biogeochemical cycles of carbon, sulfur, and free oxygen in a microbial mat. Geochim Cosmochim Acta 57, 3971-3984.

Caumette, P., Cohen, Y. \& Matheron, R. (1991). Isolation and characterization of Desulfovibrio halophilus sp. nov., a halophilic sulfate-reducing bacterium isolated from Solar Lake (Sinai). Syst Appl Microbiol 14, 33-38.
Caumette, P., Matheron, R., Raymond, N. \& Relexans, J.-C. (1994). Microbial mats in the hypersaline ponds of Mediterranean salterns (Salins-de-Giraud, France). FEMS Microbiol Ecol 13, 273-286.

Cord-Ruwisch, R. (1985). A quick method for the determination of dissolved and precipitated sulfides in cultures of sulfatereducing bacteria. $J$ Microbiol Methods 4, 33-36.

Cord-Ruwisch, R., Kleinitz, W. \& Widdel, F. (1987). Sulfatereducing bacteria and their activities in oil production. $J$ Petrol Technol 1, 97-106.

Dussault, H. P. (1955). An improved technique for staining red halophilic bacteria. J Bacteriol 70, 484 485.

Felsenstein, J. (1993). PHYLIP (Phylogeny Inference Package) version 3.5.1. Seattle: Department of Genetics, University of Washington.

Finster, K., Liesack, W. \& Tindall, B. J. (1997). Desulfospira joergensenii, gen. nov., sp. nov., a new sulfate-reducing bacterium isolated from marine surface sediment. Syst Appl Microbiol 20, 201-208.

Jørgensen, B. B. \& Cohen, Y. (1977). Solar Lake (Sinai). 5. The sulfur cycle of the benthic cyanobacterial mats. Limnol Oceanogr 22, 657-666.

Jukes, T. H. \& Cantor, C. R. (1969). Evolution of protein molecules. In Mamalian Protein Metabolism, pp. 21-132. Edited by H. N. Munro. New York: Academic Press.

Kohring, L. L., Ringelberg, D. B., Devereux, R., Stahl, D. A., Mittelman, M. W. \& White, D. C. (1994). Comparison of phylogenetic relationships based on phospholipid fatty acid profiles and ribosomal RNA sequence similarities among dissimilatory sulfate-reducing bacteria. FEMS Microbiol Lett 119, 303-308.

Krekeler, D., Sigalevich, P., Teske, A., Cypionka, H. \& Cohen, Y. (1997). A sulfate-reducing bacterium from the oxic layer of a microbial mat from Solar Lake (Sinai), Desulfovibrio oxyclinae sp. nov. Arch Microbiol 167, 369-375.

Maidak, B. L., Olsen, G. J., Larsen, N., Overbeek, R., McCaughey, M. J. \& Woese, C. R. (1997). The ribosomal database project (RDP). Nucleic Acids Res 25, 109-111.

Mesbah, M., Premachandran, U. \& Whitman, W. B. (1989). Precise measurement of the $\mathrm{G}+\mathrm{C}$ content of deoxyribonucleic acid by high-performance liquid chromatography. Int J Syst Bacteriol 39, 159-167.

Nga, D. P., Ha, D. T. C., Hien, L. T. \& Stan-Lotter, H. (1996). Desulfovibrio vietnamensis sp. nov., a halophilic sulfate-reducing bacterium from Vietnamese oil fields. Anaerobe 2, 385-392.

Ollivier, B., Hatchikian, C. E., Prensier, G., Guezennec, J. \& Garcia, J.-L. (1991). Desulfohalobium retbaense gen. nov., sp. nov., a halophilic sulfate-reducing bacterium from sediments of a hypersaline lake in Senegal. Int $J$ Syst Bacteriol 41, 74-81.

Ollivier, B., Caumette, P., Garcia, J.-L. \& Mah, R. A. (1994). Anaerobic bacteria from hypersaline environments. Microbiol $\operatorname{Rev~58,~27-38.~}$

Porteuous, L. A., Armstrong, J. L., Sadler, R. J. \& Watrud, L. S. (1994). An effective method to extract DNA from environmental samples for polymerase chain reaction amplification and DNA fingerprint analysis. Curr Microbiol 29, 301-307.

Saitou, N. \& Nei, M. (1987). The neighbor-joining method: a new method for reconstructing phylogenetic trees. Mol Biol Evol 4, 406-425.

Skyring, G. W. (1987). Sulfate reduction in coastal environments. Geomicrobiol J 5, 295-374. 
Tamaoka, J. \& Komagata, K. (1984). Determination of DNA base composition by reversed-phase high performance liquid chromatography. FEMS Microbiol Lett 25, 125-128.

Tardy-Jacquenod, C., Magot, M., Laigret, F., Kaghad, M., Patel, B. K. C., Guezennec, J., Matheron, R. \& Caumette, P. (1996). Desulfovibrio gabonensis sp. nov., a new moderately halophilic sulfate-reducing bacterium isolated from an oil pipeline. Int $J$ Syst Bacteriol 46, 710-715.

Tardy-Jacquenod, C., Magot, M., Patel, B. K. C., Matheron, R. \& Caumette, P. (1998). Desulfotomaculum halophilum sp. nov., a new halophilic sulfate-reducing bacterium isolated from oil production facilities. Int $J$ Syst Bacteriol 48, 333-338.

Vainshtein, M., Hippe, H. \& Kroppenstedt, R. M. (1992). Cellular fatty acid composition of Desulfovibrio species and its use in classification of sulfate-reducing bacteria. Syst Appl Microbiol 15, 554-566.

Visuvanathan, S., Moss, M. T., Stanford, J. L., Hermon-Taylor, J. \& McFadden, J. J. (1989). Simple enzymatic method for isolation of DNA from diverse bacteria. J Microbiol Methods 10, 59-64.
Widdel, F. (1980). Anaerober Abbau von Fetsäuren und Benzoesäure durch neu isolierte Arten sulfatreduzierender Bakterien. PhD thesis, Göttingen University.

Widdel, F. \& Bak, F. (1992). Gram-negative mesophilic sulfatereducing bacteria. In The Prokaryotes: a Handbook of the Biology of Bacteria; Ecophysiology, Isolation, Identification, Applications, 2nd edn, pp. 3353-3378. Edited by A. Balows and others. New York: Springer.

Widdel, F. \& Pfennig, N. (1981). Studies on dissimilatory sulfatereducing bacteria that decompose fatty acids. I. Isolation of new sulfate-reducing bacteria enriched with acetate from saline environments. Description of Desulfobacter postgatei gen. nov., sp. nov. Arch Microbiol 129, 395-400.

Zhilina, T. N., Zavarzin, G. A., Rainey, F. A., Pikuta, E. N., Osipov, G. A. \& Kostrikina, N. A. (1997). Desulfonatronovibrio hydrogenovorans gen. nov., sp. nov., an alkaliphilic, sulfate-reducing bacterium. Int J Syst Bacteriol 47, 144-149.

ZoBell, C. E. (1958). Ecology of sulfate-reducing bacteria. Producers' Monthly 22, 12-29. 